\title{
Svemir ni iz čega i kozmologijski argumenti
}

\author{
Goran Lojkic**
}

\begin{abstract}
Sažetak
Cilj je rada opisati konceptualni odnos izmedu pojma spontana nastanka svemira ni iz čega i kozmologijskih argumenata. Svaka inačica kozmologijskoga argumenta počiva na tri središnje tvrdnje, uključujući one koje se u radu nazivaju načelom objašnjenja i načelom utemeljenja. Tvrdi se da obrana metafizičke mogućnosti spontana nastanka svemira ni iz čega obvezuje na odbacivanje barem jednoga od tih načela, no da odbacivanje bilo kojega od njih povlači neplauzibilne metafizičke posljedice.
\end{abstract}

Ključne riječi: kozmologijski argument; sirove činjenice; načelo objašnjenja; načelo utemeljenosti; prvi uzrok

\section{Uvod}

Tradicionalno su ateistički mislioci argumentirali da ako je svemir beskonačno star, tj. ako svemir nije nastao prije konačno mnogo vremena ili, malo općenitije, ako ne postoji početni vremenski trenutak (ili limit) postojanja svemira, nema ni teorijske potrebe za nečim poput transcendentnoga "prvoga uzroka" svemira. Tradicionalni je teistički odgovor da je pitanje je li svemir beskonačno ili pak samo konačno star sámo po sebi irelevantno za pitanje postoji li metafizički prvi uzrok: većina standardnih kozmologijskih argumenata za Božju opstojnost, primjerice prva tri od slavnih pet putova Tome Akvinskoga, niti izričito pretpostavljaju konačnu starost svemira niti o toj pretpostavci ovise. ${ }^{1}$ Međutim, po-

* Dr. sc. Goran Lojkić, Institut za filozofiju. Adresa: Ulica grada Vukovara 54, 10000 Zagreb, Hrvatska. ORCID iD: https://orcid.org/0000-0001-8859-4146. E-adresa:goran@ifzg.hr

1 Primjerice, iako sâm doista smatra da stvoreni svijet ima vremenski početak, Toma Akvinski u De aeternitate mundi argumentira da »nije nužno da djelatni uzrok, tj. Bog, trajanjem prethodi svom učinku « (Toma Akvinski, 2005, 160) i da je stoga, kako bismo to danas kazali, metafizički moguće da »nešto postoji oduvijek, a ipak zavisi od Boga uzročno u cjelini svoga bića « (Toma Akvinski, 2005, 158). Suvremeni tomistički filozof Edward Feser pojašnjava da je Akvinac »glasovito smatrao da ne može biti dokazano filozofijski da svijet ima početak u vremenu « te da Toma, dokazujući opstojnost prvoga uzroka, ustvari »argumentira da, čak i ako je svijet oduvijek postojao, Bog bi svejedno morao postojati ovdje $i$ sada, u protivnom bi izvjesna obilježja koja [svijet] ovdje i sada pokazuje bila neobjašnjiva « (Feser, 2009, 64). Sve citate u tekstu koji su u izvorniku na engleskom jeziku preveo je autor rada. 
sljednjih se je godina, posebice u popularno-znanstvenim tekstovima i općenito u neakademskim raspravama, raširila tvrdnja da nam suvremena kozmologija može objasniti na koji je način svemir mogao nastati "iz ničega" — sugerirajući time da nam znanost može ponuditi objašnjenje spontana nastanka svemira ni iz čega, nastanka svemira "sama od sebe", tj. u odsutnosti bilo kakva vanjska djelatna uzroka - uklanjajući time potrebu za stvoriteljem svemira čak i ako svemir doista ima temporalni početak. ${ }^{2}$ Predvidivo, već se i na površno čitanje pokazuje da ta tvrdnja redovito uključuje kreativnu semantičku intervenciju u značenje riječi "ništa": umjesto izraza univerzalne negacije, postaje ona u autorovu žargonu netehničkim ekstravagantnim alternativnim imenom za ovu ili onu vrstu fizičkih entiteta - neke postojeće "stvari”, nečega - tipično za određenu vrstu fizikalnih polja ili stanja, primjerice za ono što fizičari obično nazivaju kvantnim vakuumom. Drugim riječima, pokazuje se da ono što se u takvim tekstovima zapravo opisuje kada se govori o nastanku svemira "iz ničega" nije nastanak svemira ni iz čega, nego tek nastanak određenih vrsta fizičkih entiteta iz nekih drugih, teorijski fundamentalnijih vrsta fizičkih entiteta, i samih reguliranih određenim skupom fizikalnih zakona. Ilustrativan je primjer toga pomaka značenja izraza "ništa" popularno-znanstveni tekst Kako je svemir mogao nastati iz ničega? fizičara Ivice Puljka:

»A što je "ništa"? Najintuitivnija definicija ničega bila bi: kada iz nekog dijela prostora maknemo sve čestice, tada u njemu ostane - NIŠTA. To se u znanstvenom jeziku naziva "vakuum". [...] Kada iz nekog dijela prostora maknemo sve čestice, u njemu i dalje postoji energija u obliku takozvanih kvantnih fluktuacija iz kojih neprestano nastaje beskonačan broj virtualnih čestica i antičestica. [...] Iz ovakvih kvantnih fluktuacija vjerojatno je nastao cijeli naš svemir, a onda u konačnici i mi sami« (Puljak, 2018).

No, naravno, nastanak fizikalnih čestica fluktuacijama kvantnoga vakuuma upravljanim određenim fizikalnim zakonima trivijalno nije nastanak ni iz čega — ništa više nego što je primjerice nastanak pojedinih makroskopskih predmeta različitim rekonfiguracijama fizikalnih čestica nastanak ni iz čega — i stoga fizikalna teorija u pitanju ne opisuje nastanak svemira ex nihilo. Opisujući nastanak jedne vrste fizičkih entiteta iz neke druge vrste prethodno postojećih fizičkih entiteta, ona se ne čini čak ni rubno relevantnom za pitanje postoji li metafizički prvi uzrok svemira i jesu li argumenti koji pokušavaju dokazati opstojnost prvoga uzroka uspješni ili nisu. Da bi što bilo metafizički prvim uzrokom svemira, ono bi, između ostaloga, moralo biti u primjerenom smislu i uzrokom opstojnosti kvan-

2 Govoreći u tom kontekstu o nastanku svemira "iz ničega", ne misli se, dakle, ni na što slično Božjemu stvaranju ni iz čega — doktrini koju kršćani i mnogi drugi teisti prihvaćaju i koja, između ostaloga, eksplicira pojam Boga kao svestvoritelja, tj. kao onoga o kome sve što jest (i sve što može biti) kauzalno ili ontologijski ovisi. Creatio ex nihilo očito implicira da postoji nešto što kauzalno prethodi stvorenju — naime, stvoritelj — a ateistička tvrdnja da je svemir nastao (ili da je barem mogao nastati) "iz ničega” sugerira upravo to da je metafizički moguće da nastanku svemira kauzalno ne bi prethodilo ništa, što bi doista, čini se, impliciralo tvrdnju da Bog ne postoji (usp. bilj. 3). Tu razliku povremeno u tekstu naglašavamo govoreći o spontanu nastanku svemira ni iz čega. 
tnoga vakuuma, ništa manje nego bilo kojega drugoga fizičkoga entiteta, baš kao i uzrok toga da zakoni prema kojima čestice nastaju kvantnim fluktuacijama jesu upravo oni koji jesu. No teorija koja bi opisivala nastanak fizikalnih čestica koje konstituiraju svemir pozivanjem na kvantni vakuum i određeni skup postuliranih fizikalnih zakona ništa nam sama po sebi ne bi govorila o tome postoji li ili ne kakav daljnji uzrok opstojnosti kvantnoga vakuuma i relevantnih zakona prirode.

Dakako, iz toga što pojedina fizikalna teorija (ili određena interpretacija fizikalne teorije) sama ne opisuje nastanak svemira ni iz čega ne slijedi ujedno da neka fizikalna teorija to načelno ne bi mogla učiniti. Štoviše, čak i ako fizika općenito ne bi mogla ponuditi teoriju nastanka svemira ni iz čega, ne bi to još uvijek značilo da spontani nastanak svemira ni iz čega nije metafizički moguć. U ovom radu pokušavamo pobliže analizirati značenje tvrdnje da je svemir mogao spontano nastati ni iz čega te opisati konceptualne i logičke odnose između pojma nastanka svemira ni iz čega i kozmologijskih argumenata za opstojnost metafizički prvoga uzroka. U prvom odsječku, kako bismo zavaravajuće tvrdnje da nam suvremena fizika pokazuje kako je svemir mogao nastati "iz ničega" stavili po strani, iznosimo načelni (i zapravo bjelodan) razlog zašto nešto poput nastanka ni iz čega ne bi moglo biti opisivo fizikalnom teorijom. U drugom odsječku ukratko analiziramo tri skupine kozmologijskih argumenata, tvrdeći da dokaz opstojnosti metafizički prvoga uzroka u svakoj od njih počiva na tri središnje tvrdnje, među kojima su dvije vrste metafizičkih načela koje u tekstu nazivamo načelom objašnjenja i načelom utemeljenja. U završnom odsječku pokušavamo preciznije opisati što bi izraz "nastanak svemira ni iz čega" uopće mogao značiti $\mathrm{i}$ ispitujemo u kakvu bi odnosu spontani nastanak ex nihilo stajao spram spomenutih metafizičkih načela.

\section{Svemir ni iz čega}

U predgovoru svojoj popularno-znanstvenoj knjizi A Universe from Nothing: Why There Is Something Rather Than Nothing, poznati fizičar i popularizator znanosti Lawrence M. Krauss piše da rezultati suvremene znanosti »sugeriraju da dobiti nešto ni iz čega nije problem « i da »[š]toviše, svi znakovi sugeriraju da to jest način na koji je naš svemir mogao nastati« (Krauss, 2012, xiii). Navodno znanstveno objašnjenje nastanka svemira ni iz čega Krauss iznosi kao (mogući) odgovor na ona pitanja koja su filozofe tradicionalno vodila zaključiti da je potrebno nešto poput »prvoga uzroka, kako bi to Platon, Akvinac ili moderna Rimokatolička crkva mogli kazati, i time pretpostaviti neko božansko biće: stvoritelja svega što jest i svega što će ikada biti« (Krauss, 2012, xii). Ako bi Krauss bio u pravu tvrdeći da suvremena znanost sugerira da bi svemir mogao spontano nastati ni iz čega, doista bismo u rukama imali snažan argument da Bog ne postoji. ${ }^{3}$ No, unatoč njegovim izričitim tvrdnjama — i unatoč samomu naslovu

3 Sama metafizička mogućnost nastanka svemira ni iz čega — štoviše, općenitije (pretpostavivši da učinak ne može vremenski prethoditi uzroku), sama mogućnost potpuno neuzrokovana nastan- 
i podnaslovu knjige - niti knjiga pokušava opisati nastanak svemira ni iz čega niti je Kraussova spekulativna kozmologija imalo relevantna za pitanje postoji li Bog. Posebno, prihvaćate li neku inačicu kozmologijskoga argumenta za opstojnost metafizički prvoga uzroka, u $A$ Universe from Nothing ne ćete pronaći dobar razlog za promijeniti mišljenje: istinitost ili neistinitost središnjih tvrdnji većine kozmologijskih argumenata ne ovisi ni o čemu o čemu Krauss u knjizi govori. ${ }^{4}$

Ono što Krauss pokazuje u najboljem je slučaju to da, pretpostavimo li stanoviti skup fizikalnih zakona (uključujući cjelokupni teorijski arsenal kvantne mehanike), moguće je (možda i plauzibilno) neka važna svojstva svemira (postojanje prostora i materije, poseban oblik pojedinih fizikalnih zakona i sl.) i nastanak određenih vrsta entiteta u svemiru (primjerice fizikalnih čestica) objasniti kao učinak prethodno danih fundamentalnijih vrsta entiteta (primjerice određenih vrsta poljā). Ako je Krauss u pravu, govori nam to zanimljivu i važnu stvar. Međutim, pokazati da se nastanak pojedinih vrsta fizikalnih entiteta i zakona može objasniti u terminima nekih fundamentalnijih vrsta fizikalnih entiteta i zakona jednostavno nam ništa ne govori o tome zašto uopće postoje fizikalni entiteti i zakoni. Krauss stoga ne opisuje nastanak svemira ni iz čega niti odgovara na ono drevno pitanje na koje aludira podnaslovom knjige. ${ }^{5}$

ka (uz određene kvalifikacije poput dopuštanja nedeterminističkoga uzrokovanja) — povlači da Bog ne postoji. Naime, čini se pojmovnom istinom da bi, ako Bog postoji, sve ostalo što uopće može postojati moralo biti, ako bi postojalo, učinak Božjega kauzalnoga djelovanja ili na neki već prikladan način o njem kauzalno ili ontologijski ovisiti. Doduše, izgleda da sâm Krauss, pišući da bi svemir mogao nastati ni iz čega, nema na umu metafizičku, nego epistemičku mogućnost jer dodaje da »možda nikada ne ćemo imati dovoljno empirijskih informacija za jednoznačno razriješiti to pitanje « (Krauss, 2012, xiii).

4 Izuzetak je tzv. kalam kozmologijski argument, uspješnost kojega ovisi o istinitosti tvrdnje da je svemir počeo postojati prije samo konačno mnogo vremena. Za pitanje ima li svemir konačnu prošlost očito jest relevantno što suvremena kozmologija ima za reći. Također, fizikalne se teorije (primjerice specijalna teorija relativnosti) čine relevantnima za pitanje koja je od konkurentskih metafizičkih teorija vremena istinita i time za pitanje kako točno shvatiti tvrdnju da svemir ima konačnu prošlost. Ako je istinita teorija vremena tzv. teorija A, konačna prošlost svemira povlači da je svemir doista u punom ili jakom smislu nastao, počeo postojati. Ako je istinita tzv. teorija B, to nije slučaj. Kalam argument, čini se, pretpostavlja istinitost teorije A. William Lane Craig, najistaknutiji suvremeni branitelj kalam argumenta, piše: »Od početka do kraja, kalam kozmologijski argument temelji se na A-teoriji vremena« (Craig i Sinclair, 2009, 183).

5 Riječ je o standardnom i očekivanom prigovoru koji su Kraussovoj knjizi uputili brojni filozofi, čak i u popularnom tisku. Primjerice, filozof znanosti David Albert u vrlo oštrom kritičkom osvrtu na Kraussovu knjigu za The New York Times Book Review piše: »Činjenica da neki rasporedi polja odgovaraju postojanju čestica a neki ne nije ni mrvicu tajanstvenija od činjenice da neki mogući rasporedi mojih prstiju odgovaraju postojanju šake a neki ne. Činjenica da čestice mogu nastajati i nestajati tijekom vremena kako se ta polja preraspoređuju nije ni mrvicu tajanstvenija od činjenice da šaka može nastajati i nestajati tijekom vremena kako se preraspoređuju moji prsti. Nijedno od tih nastajanja i nestajanja — gledate li ispravo na njih — nije nigdje ni blizu stvaranju ni iz čega (Albert, 2012). Slično Davor Pećnjak (2014, 158-160), analizirajući tri moguće fizikalne interpretacije nastanka svemira "iz ničega", zaključuje da svaka od njih objašnjava nastanak svemira pozivajući se na neku vrstu (ontologijski fundamentalnijih) kontingentnih entiteta i/ili zakona, opstojnost kojih nije objašnjena, nego postulirana teorijom u pitanju. Stoga ni u jednoj od njih nije riječ o opisu nastanka svemira ni iz čega. 
To je, dakako, predvidiv rezultat: prima facie, čini se očitim da je konceptualno nemoguće imati fizikalno objašnjenje nastanka svemira ni iz čega. Svaka fizikalna teorija, uključujući nekakvu idealnu ultimativnu znanstvenu "teoriju svega", nužno mora postulirati određenu kolekciju eksplanacijski primitivnih entiteta i zakona, tj. entiteta kojih se opstojnost ne može dalje objasniti samom teorijom u pitanju (primjerice kao konstituirane nekim "temeljnijim" vrstama entiteta) i zakona koji se ne mogu dalje svesti na neke "dublje" zakone postulirane istom teorijom. Među tim postuliranim entitetima i zakonima morali bi se pak nalaziti, dok god je riječ o fizikalnoj teoriji, i fizički entiteti i zakoni prirode koji opisuju ili upravljaju interakcijom tih fizičkih entiteta. Međutim, ako doista svaki fizikalni opis stvarnosti među svojim postuliranim entitetima i zakonima nužno mora sadržavati fizičke entitete i zakone interakcije fizičkih entiteta (a ne samo, recimo, matematičke predmete poput skupova te logičke i matematičke poučke i sl.) te ako pritom — kako se čini plauzibilnim pretpostaviti — fizički entiteti nisu vrsta stvari koje bi mogle postojati metafizički nužno a se, kozmologijski argumenti iz kontingentnosti zadržavaju svu svoju snagu, posve neovisno o tome koje bi se točno vrste kontingentnih entiteta na kraju mogle pokazati kao fundamentalni fizikalni entiteti i neovisno o tome imaju li fundamentalni fizikalni zakoni ovaj ili onaj oblik. Slično tomu, ako bi svaka fizikalna teorija nužno morala pretpostaviti da postoji nešto poput kauzalnosti i promjene, jednako vrijedi i za druge standardne kozmologijske argumente. Kozmologijski argumenti jednostavno ne ovise o tome koja je fizikalna teorija istinit opis fizičkoga svijeta ni o tome koji su fizički entiteti njegove fundamentalne sastavnice. ${ }^{6}$

Zanimljivo je, međutim, zapitati se kako bi uopće mogao izgledati legitiman opis nastanka svemira ni iz čega, je li spontani nastanak svemira ni iz čega metafizički moguć te kako bi se preciznije mogao opisati konceptualni odnos između nastanka ni iz čega i kozmologijskih argumenata. Tim se pitanjima bavimo dalje u tekstu.

\section{Kozmologijski argumenti i sirove činjenice}

Važan razred teističkih argumenata - možda najvažniji — čine tzv. kozmologijski argumenti za Božju opstojnost. Standardni kozmologijski argumenti tipično se sastoje od dva dijela ili stadija: u prvom se dijelu argumenta pokušava dokazati opstojnost metafizički prvoga uzroka, a u drugom se dijelu pokušava pokazati da prvi uzrok (nužno) posjeduje dovoljno klasičnih božanskih atributa za opravdanje identifikacije prvoga uzroka kao Boga, kako se izraz "Bog" tradicionalno razumije u metafizici, posebice u naravnoj teologiji (usp. Rowe, 2007, 20). Neovisno o razlikama među njima, prvi dio svakoga kozmologijskoga argumenta sadržava tri središnje tvrdnje, iz kojih, uz stanovite pozadinske pretpostavke, opstojnost metafizički prvoga uzroka tipično vrlo jednostavno slijedi. Njihova

6 Uz izuzetak, kako smo pojasnili u bilj. 4, kalam kozmologijskoga argumenta. 
obrana stoga tvori glavni dio prve faze argumenta. Ovisno o konkretnom obliku tih triju središnjih tvrdnji, kozmologijske argumente možemo klasificirati u tri velike skupine: tomističke, kalam i leibnizovske kozmologijske argumente (usp. Pruss, 2009, 25).

Prva je središnja tvrdnja kozmologijskoga argumenta konstatacija određene "velike činjenice" ili opis neke "globalne" ili "kozmičke" karakteristike svijeta za koju tražimo objašnjenje. Primjerice, u slučaju prvoga od glasovitih pet putova Tome Akvinskoga velika je činjenica to da se neke stvari u svijetu mijenjaju (odnosno, u Tominu aristotelovskom nazivlju, "kreću" ili "gibaju”), tj. poprimaju kao aktualna neka svojstva koja su im prethodno pripadala samo potencijalno. U slučaju kalam kozmologijskoga argumenta tvrdi se da je svemir nastao, da nema beskonačnu prošlost. U najjednostavnijoj inačici leibnizovskoga kozmologijskoga argumenta odgovarajuća je velika činjenica to da svemir nije metafizički nužan, tj. da svemir postoji tek kontingentno. ${ }^{7}$

Druga središnja tvrdnja kozmologijskoga argumenta iznosi neko prikladno kauzalno ili eksplanacijsko metafizičko načelo koje povlači da velika kozmička činjenica u pitanju doista ima (kauzalno) objašnjenje. U Tominu argumentu to je načelo da (nužno) samo ona bića koja aktualno postoje mogu aktualizirati neku potenciju. U kalam argumentu načelo je da (nužno) za svaki entitet koji je nastao, tj. koji ima temporalni početak ili limit, postoji neki djelatni uzrok njegove opstojnosti. U leibnizovskom argumentu, to načelo može biti da (nužno) svaka kontingentno istinita propozicija ima objašnjenje.

Treća je središnja tvrdnja kozmologijskoga argumenta određeno načelo regularnosti ili utemeljenosti, čija je teorijska funkcija isključenje cirkularnih objašnjenja i beskonačnoga regresa kao mogućih objašnjenja početne kozmičke činjenice. Ta tvrdnja u tomističkom argumentu glasi da je (nužno) svaki esencijalno uređen kauzalni niz dobro utemeljen (well-founded). ${ }^{8} \mathrm{U}$ kalamu bi se treća tvrdnja mogla formulirati jednostavno kao tvrdnja da (nužno) nijedan entitet nije sâm uzrok svoje opstojnosti. Slično, u nekim inačicama leibnizovskoga argumenta istu ulogu može imati tvrdnja da se (nužno) uzrok i učinak ne mogu preklapati, u smislu da ne mogu imati zajednički mereološki dio.

7 Primjerice kod Williama Craiga (2007). On doduše ne navodi tu tvrdnju kao eksplicitnu premisu u svojem osnovnom prikazu leibnizovskoga argumenta (Craig, 2007, 106), ali njezina je obrana glavni dio argumentacije u prilog premise da ako svemir ima objašnjenje svoje opstojnosti, to je objašnjenje Bog. Međutim, postoje razlozi zbog kojih bi tko radije dao prednost nekoj drukčijoj formulaciji — između ostaloga, želimo li sačuvati izraz "svemir" za ukupnost prostorno-vremenske ili općenito fizičke stvarnosti, a ujedno dopustiti mogućnost ne-fizičkih kontingentnih bića (primjerice anđela). Odgovarajuća tvrdnja kod Roberta Koonsa (1997) ona je o postojanju mereološke sume svih potpuno kontingentnih činjenica. Kod Alexandera Prussa (2009) analognu ulogu ima tzv. velika konjunktivna kontingentna činjenica, tj. konjunkcija svih kontingentno istinitih propozicija. Joshua Rasmussen (2010) pak argument formulira u terminima stanja stvarī, pri čemu je velika činjenica postojanje stanja stvarī koje naziva maksimalno konzistentnim stanjem egzistencije (i time postojanje mogućega svijeta u kojem je to stanje stvarī uspostavljeno).

8 Odnosno, bliže Tominoj terminologiji, da se nijedan kauzalni niz uređen per se ne sastoji samo od drugotnih ili instrumentalnih uzroka. Za u Tominu argumentu ključnu razliku između uzročnih nizova uređenih per se i uzročnih nizova uređenih per accidens usp. Feser, 2014, 164-171. 
Naravno, za sve tri tvrdnje, u sve tri vrste argumenata, postoji raspon mogućih varijacija i kvalifikacija i moguće su manje ili veće razlike u formulacijama, ovisno već o teorijskom kontekstu i različitim pozadinskim razmatranjima. Između ostaloga, kako smo naznačili riječju "nužno" u zagradama, zastupnik kozmologijskoga argumenta mogao bi metafizička načela koja rabi uzeti bilo samo kao istinita u aktualnom svijetu bilo kao nužno istinita, tj. istinita u svakom mogućem svijetu. ${ }^{9} \mathrm{Ne}$ čini se plauzibilnim da bi ta metafizička načela bila istinita u nekim a neistinita u drugim mogućim svjetovima, pa ćemo nadalje, govoreći o njima, radi jednostavnosti pretpostavljati da su, ako su uopće istinita, istinita nužno. ${ }^{10}$

Drugu središnju tvrdnju kozmologijskoga argumenta nazovimo "načelo objašnjenja". Načelo objašnjenja isključuje mogućnost relevantnih sirovih činjenica (brute facts). Što su sirove činjenice? Sirovima nazivamo one činjenice za koje ne postoji nikakav uzrok, razlog ili objašnjenje, ${ }^{11}$ ne samo u smislu da objašnjenje ne znamo ili da ga ni načelno ne bismo mogli znati — nije tu riječ tek o epistemologijskoj kategoriji — nego da uopće ne postoji objašnjenje činjenice u pitanju. Ako je neko uspostavljeno (obtained) kontingentno stanje stvarī takvo da ne postoji nikakav uzrok koji je uspostavio to stanje stvarī, nikakvo objašnjenje zašto je to stanje stvarī uspostavljeno, to je stanje stvarī sirova činjenica. Primjerice, kaže li vam tko da se na zidu u njegovoj dnevnoj sobi pojavila slika s prikazom žutih i crvenih cvjetova, ali da tu sliku nitko nije naslikao i postavio na zid te da, štoviše, ta slika nije nastala čak ni kao rezultat malo vjerojatnoga niza kvantnih događaja ni izravnom Božjom intervencijom, da stvarno nema nikakva uzroka ni objašnjenja zašto ta slika postoji, tada vam taj netko tvrdi da je nastanak slike na njegovu zidu sirova činjenica. Načelo objašnjenja kaže nam da takve slike nema. Načelo objašnjenja tvrdi da elektroni, mrtve prirode, ribarska naselja i svemiri ne uskaču neuzrokovani u bitak, da postoji razlog zašto se teški atomi raspadaju na pojedi-

9 Pojam mogućih svjetova ustalio se je kao standardno konceptualno oruđe analitičke filozofije. Intuitivno, izraz "mogući svijet" odnosi se jednostavno bilo na koji način na koji bi svijet (shvaćen u širokom smislu kao stvarnost ili zbilja općenito) mogao biti. Metafizički je nužno istinito, po definiciji, ono što je istinito u svim mogućim svjetovima, tj. ono što bi bilo istinito bez obzira na način na koji bi stvarnost mogla biti. Metafizički je moguće istinito pak ono što je istinito u barem jednom mogućem svijetu.

10 Koliko je do prvoga stadija kozmologijskih argumenata, tvrdnja da su metafizička načela u pitanju istinita u aktualnom svijetu u većini je slučajeva dovoljna, no ne i u svima. Primjerice u Rassmussenovu (2010) leibnizovskom argumentu polazna je velika činjenica ta da postoji mogući svijet u kojem je uspostavljeno maksimalno konzistentno stanje egzistencije i stoga, da bi argument držao vodu, odgovarajuće načelo mora vrijediti u tom mogućem svijetu. Međutim, sama metafizička mogućnost neistinitosti relevantnih metafizičkih načela — i time postojanje mogućega svijeta u kojem, recimo, neki kontingentni entiteti nemaju uzrok — nekompatibilna je s drugim stadijem argumenta, tj. s tvrdnjom da je prvi uzrok Bog (usp. bilj. 3).

11 U tekstu izraz "činjenica” rabimo relativno ležerno i u netehničkom smislu, ne obvezujući se na neku posebnu pozadinsku ontologiju. U odlomku izraz koristimo za uspostavljena stanja stvarī, ali alternativno bismo činjenice mogli shvatiti primjerice jednostavno kao istinite propozicije te bi sirove činjenice tada bile kontingentno istinite propozicije koje su istinite bez ikakva razloga ili objašnjenja. U nekim je formulacijama kozmologijskoga argumenta povlačenje razlike između činjenica i istinitih propozicija ključno za formulaciju prikladnoga načela objašnjenja - usp. O'Connor $(2012,84)$ — ali ta nam je razlika u pozadinskoj ontologiji ovdje nebitna. 
ne atome i čestice radije nego na zbirke ljubavne poezije i konjaničke pukovnije, da to što su ruže crvene a Zagorje zeleno ima neko objašnjenje. ${ }^{12}$

Treću središnju tvrdnju kozmologijskoga argumenta nazovimo "načelo utemeljenosti”. Načelo utemeljenosti isključuje mogućnost objašnjenja velike činjenice pomoću neutemeljenih (non-well-founded) eksplanacijskih struktura, primjerice pozivanjem na metafizički "bizarne" scenarije poput kauzalnih petlji ili na neutemeljene beskonačne kauzalne lance poput, recimo, temporalno konačnih nizova kauzalno povezanih događaja bez prvoga člana niza. Na primjeru ce biti jasnije što to znači. Recimo da djevojka svojemu zaručniku, s kojim se složila živjeti u čistoći prije braka, kaže da je trudna. Međutim, dodaje, bez brige, nije ga prevarila — postoji sasvim nevino objašnjenje za njezinu trudnoću. $\mathrm{U}$ nekom početnom trenutku $t_{0}$ nije bila trudna, kaže, no u svakom trenutku $t$ između početnoga trenutka $t_{0}$ i sadašnjega trenutka $t^{*}$ u njezinoj je utrobi dijete. Razumije da mu se na prvi pogled čini plauzibilnim da mora postojati neki vanjski uzrok nastanka djeteta, ali kada se bolje pogleda, vidi se da zapravo nije tako. Naime, postojanje djeteta u nekom trenutku $t$ može se objasniti jednostavno time što dijete postoji u nekom ranijem trenutku $t$ '. Zašto dijete postoji u 12:01? Zato što postoji u 12:00 i jer između 12:00 i 12:01 ništa nije prouzročilo da ono prestane postojati. Ali, ako ne postoji početni trenutak postojanja djeteta, koji god trenutak $t$ uzeli, uvijek postoji neki raniji trenutak $t$ ' između $t_{0}$ i $t$. Stoga se, ako početnoga trenutka nema, postojanje djeteta u baš svakom trenutku $t$ može objasniti postojanjem djeteta u nekom ranijem trenutku $t^{\prime}$. No, objasnivši zašto dijete postoji u svakom trenutku u kojem postoji, u potpunosti smo objasnili zašto dijete postoji i nema potrebe pretpostavljati da mora postojati neki dodatni vanjski uzrok koji je doveo do trudnoće. Dijete je u izvjesnom smislu uzrok sama sebe, postojanje djeteta samoobjašnjavajuća je činjenica. ${ }^{13}$ Kako vam se čini to objašnjenje? Biste li povjerovali zaručnici? Ako je načelo utemeljenosti istinito, ne biste trebali. Načelo utemeljenosti kaže nam da kokoš ne može snijeti jaje iz

12 Načelo objašnjenja u svakom kozmologijskom argumentu isključuje za argument relevantne sirove činjenice, no može, koliko je do njega samoga — preciznije, koliko je do prvoga stadija argumenta (usp. bilj. 3 i 10) — dopustiti da neke sirove činjenice postoje ili da su barem moguće. Primjerice, prvi tomistički argument, ako je uspješan, dokazuje da u aktualnom svijetu postoji uzrok "gibanja", koji je sâm kauzalno neovisan, tj. neuzrokovan. No, na prvi pogled, čini se da argument sam po sebi dopušta da postoji neki mogući svijet u kojem taj prvi uzrok ne postoji — mogući svijet, primjerice, u kojem postoje samo apstraktni entiteti (matematički predmeti, propozicije i sl.) i u kojem stoga ne postoji nikakva promjena. Značilo bi to da prvi uzrok, iako neuzrokovan, nije metafizički nužan. No, kako je neuzrokovan, čini se da ništa ne bi moglo objasniti zašto prvi uzrok postoji u svijetu u kojem postoji. Drugim riječima, opstojnost prvoga uzroka bila bi sirova činjenica. Međutim, dvije stvari tu valja napomenuti. Kao prvo, pojedini kozmologijski argument ne treba gledati u izolaciji. Nije epistemički vjerojatno da bi od kozmologijskih argumenata samo prvi Akvinčev put bio uspješan. Argument iz promjene dokazuje da postoji neki neuzrokovani prvi uzrok promjene, ali leibnizovski argument, recimo, dokazuje da je prvi uzrok metafizički nužan, tj. da njegova opstojnost nije sirova činjenica. Kao drugo, i važnije, ako je Tomina analiza ispravna, da bi nešto bilo neuzrokovanim prvim uzrokom, ono mora biti čista aktualnost (actus purus), a iz toga - posve neovisno o drugim kozmologijskim argumentima — slijedi da prvi uzrok postoji metafizički nužno.

13 Primjer je gotovo verbatim preuzet iz: Lojkić, 2019, 49-50. 
kojega se ona sama izlegla. Kaže nam također da, čak i ako bismo mogli objasniti svako jaje referiranjem na koku koja ga je snijela, a svaku koku referiranjem na jaje iz kojega se izlegla, time ne bismo objasnili zašto uopće postoje kokoši i jaja. Pojavi li se odjednom nad vašom glavom padajući glasovir, načelo utemeljenosti govori vam da nešto nedostaje u objašnjenju da u nekom trenutku $t_{0}$ glasovir nije postojao, ali da je postojanje glasovira u svakom trenutku $t$ nakon $t_{0}$ objašnjeno pozivanjem na postojanje glasovira u nekom ranijem trenutku $t^{\prime}$ između $t_{0} \mathrm{i} t$ - čak i ako bi bilo tako, tvrdi načelo utemeljenosti, to ne bi objasnilo zašto se nad vama pojavio padajući glasovir. Vrijedi to i za svemir sam, jednako koliko i za nerođenu djecu i padajuća glazbala. Vrlo općenito, načelo utemeljenosti kaže nam da scenariji poput gore opisanih nisu eksplanacijski potpuni. Na cirkularne i beskonačno regresivne nizove (kauzalnih) objašnjenja također se odnosi načelo objašnjenja: ili mora postojati neko dodatno objašnjenje cijeloga niza ili, ako dodatnoga objašnjenja nema, takvi scenariji opisuju sirove činjenice i stoga su nemogući. ${ }^{14}$

\section{Ex nihilo nihil fit}

Načelo objašnjenja i načelo utemeljenosti, u sve tri vrste kozmologijskih argumenata, kompatibilni su s vječnošću svemira. Početne velike činjenice u tomističkim i leibnizovskim argumentima (no ne i u kalamu) također ne pretpostavljaju da je svemir samo konačno star. Stoga je moguće biti teist, primjerice aristotelovskoga ili novoplatoničkoga tipa, a ujedno konzistentno nijekati da je svemir nastao prije konačno mnogo vremena. ${ }^{15} \mathrm{~S}$ druge strane, načelo objašnjenja i načelo utemeljenosti, u sve tri vrste kozmologijskoga argumenta, zajedno isključuju mogućnost spontana nastanka svemira ni iz čega, bilo da svemir ima neki početni trenutak $t_{0}$ u kojem počinje postojati, bilo da je, kao u primjeru padajućega glasovira, $t_{0}$ limit u kojem svemir ne postoji, ali postoji u svakom trenutku nakon $t_{0} .{ }^{16}$

14 Načelo utemeljenosti u nekim inačicama kozmologijskoga argumenta isključuje mogućnost neutemeljenih eksplanacijskih struktura (primjerice kauzalnih petlji), a u nekima samo implicira da i one same, ako postoje, moraju imati objašnjenje koje referira na nešto van njih samih (primjerice neki vanjski uzrok koji je proizveo kauzalnu petlju u pitanju). U nekim je formulacijama argumenta načelo utemeljenosti samo implicitno pretpostavljeno, u nekima je eksplicitno izneseno, a u nekima su pak načelo utemeljenosti i načelo objašnjenja asimilirani unutar istoga prikladno ekspliciranoga metafizičkoga načela. Primjerice, Koons (1997) kao zasebne aksiome uvodi i aksiom univerzalnosti kauzalnosti, prema kojem svaka potpuno kontingentna činjenica ima uzrok, i aksiom odvojene opstojnosti (separate existence) uzroka i učinka, prema kojem uzrok i učinak ne mogu imati zajednički mereološki dio i koji stoga (uz mereologijske aksiome) ima ulogu načela utemeljenosti u Koonsovu argumentu. S druge strane, Craig u svojoj formulaciji leibnizovskoga kozmologijskoga argumenta načelo objašnjenja i načelo utemeljenosti iznosi unutar jednoga te istoga načela, prema kojem »[s]ve što postoji ima objašnjenje svoje opstojnosti, bilo u nužnosti svoje naravi bilo u vanjskom uzroku« (Craig, 2007, 106).

15 Teist je, naravno, obvezan tvrditi da je svemir kauzalno ovisan o Bogu, ali kauzalna ovisnost o Bogu sama po sebi ne povlači konačnu starost svemira.

16 Potrebno je tu, doduše, nekoliko kvalifikacija. Primjerice, da bi nam prvi tomistički argument nešto govorio o nastanku svemira, promjenu bismo morali shvatiti dovoljno široko tako da uključuje i nastajanje, dolazak u bitak. Da bi načelo objašnjenja kalam argumenta bilo relevantno, nastanak svemira ni iz čega morao bi biti u nekom smislu temporalan događaj, odnosno moralo 
Na što mislimo kada kažemo "nastanak svemira ni iz čega"? Pokušajmo tomu izrazu dati malo preciznije značenje. Nazovimo ontologijski praznim svijetom mogući svijet u kojem ništa ne postoji, u kojem ni jedan mogući entitet nije aktualiziran, u kojem nema ni konkretnih predmeta i njihovih konfiguracija, tj. entiteta poput kvantnoga vakuuma, kvarkova, ljudskih bića, poganskih božanstava, svemirā i Boga, ni apstraktnih entiteta poput skupova, funkcija, pojmova i propozicija. Nazovimo kauzalno praznim svijetom svaki mogući svijet u kojem ne postoje konkretni entiteti. Svaki je ontologijski prazan svijet ujedno kauzalno prazan svijet, ali možda je moguć kauzalno prazan svijet koji nije ontologijski prazan svijet: svijet u kojem bi postojali samo apstraktni entiteti bio bi takav svijet. ${ }^{17}$ Svijet u kojem ne postoje konkretni entiteti kauzalno je prazan u smislu da u njem ne postoje entiteti koji imaju kauzalne moći ili koji mogu stajati u kauzalnim relacijama — drugim riječima, što god postojalo u kauzalno praznom svijetu, ono ne može biti ni uzrok ni učinak ičega. Naime, definicijska razlika između onih entiteta koje nazivamo konkretnima i onih koje nazivamo apstraktnima leži upravo u kauzalnosti: konkretni su entiteti oni koji imaju kauzalne moći ili koji mogu stajati u kauzalnim relacijama, a apstraktni su entiteti oni koji nemaju kauzalne moći i ne mogu stajati u kauzalnim relacijama. ${ }^{18}$ Glasovir je (ili barem može biti) učinak nekoga lanca uzroka, a sam može uzrokovati smrt prolaznika — baš ništa nije prouzročilo nastanak skupa realnih brojeva niti skup realnih brojeva može biti uzrok ičega. U svijetu koji je kauzalno prazan stoga očito nema ni fizikalnih zakona. ${ }^{19}$ Za svaki mogući svijet svemirom nazovimo aglomerat svih

bi se moći reći da je svemir nastao prije konačno mnogo vremena. Nijedan se od tih uvjeta ne čini posebno problematičnim. No, čak i ako bi imalo smisla govoriti o atemporalnom (ili pak omnitemporalnom) nastanku svemira ni iz čega, a koji pritom ne bi uključivao nešto poput aktualizacije potencija, spontani nastanak svemira ex nihilo protuslovio bi načelu objašnjenja i načelu utemeljenosti leibnizovskoga argumenta.

17 Plauzibilno je da postoji najviše jedan ontologijski prazan svijet. Dva potpuno prazna svijeta ne bi se razlikovala s obzirom na entitete koje sadržavaju i stoga, čini se razumnim tvrditi, ne bi se razlikovala uopće. No tada, ako je Leibnizovo načelo istovjetnosti nerazlučivoga istinito, ne bi postojali numerički različiti potpuno prazni svjetovi — bila bi riječ o jednom te istom svijetu. Također je plauzibilno da postoji najviše jedan kauzalno prazan svijet: bilo ontologijski prazan svijet, ako ne postoje apstraktni entiteti, bilo pak svijet u kojem postoje svi i samo apstraktni entiteti (ili barem svi i samo oni apstraktni entiteti koji ne superveniraju na konkretnim entitetima, poput primjerice skupova konkretnih predmeta). Naime, prema mainstream pogledu, apstraktni entiteti (ili barem oni koji ne superveniraju na konkretnim entitetima), ako postoje, postoje nužno, u svakom mogućem svijetu. Apstraktni entiteti tako ili postoje u svim mogućim svjetovima ili ni u jednom mogućem svijetu. Ako jest tako, dva se moguća svijeta razlikuju samo prema konkretnim entitetima u njima, a svi mogući svjetovi sadrže upravo iste apstraktne entitete (koji ne superveniraju na konkretnima), moguće nijedan.

18 Za pitanje o definicijskim kriterijima apstraktnih entiteta usp. Craig, 2017, 6-13. Prema Craigu, postoji takoreći univerzalan konsenzus da su apstraktni predmeti, postoje li, kauzalno inertni.

19 Zapravo, malo preciznije, kako u kauzalno praznom svijetu ne postoje konkretni entiteti, u njem su sve propozicije koje izražavaju moguće fizikalne zakone istinite na prazan način, analogno načinu na koji je propozicija da su svi jednorozi ljubičasti istinita već samim tim što jednorozi ne postoje. 
kontingentnih entiteta koji postoje u tom svijetu. ${ }^{20}$ Nastanak svemira ni iz čega tada je nastanak nekoga aglomerata kontingentnih entiteta — svejedno radilo se tu o jednoj jedinoj čestici ili nečemu poput multiverzuma — "u” kauzalno praznom svijetu ili "iz" kauzalno praznoga svijeta. ${ }^{21}$

Napisali smo gore da načelo objašnjenja i načelo utemeljenosti zajedno isključuju mogućnost nastanka svemira ni iz čega, ali vrijedi malo detaljnije opisati taj odnos. Ako su kozmologijski argumenti uspješni, nastanak svemira ni iz čega nemoguć je već samim tim što u tom slučaju uopće ne postoji kauzalno prazan mogući svijet. Naime, iz kozmologijskih argumenata — ponegdje možda uz pokoju dodatnu plauzibilnu pretpostavku — slijedi da metafizički prvi uzrok postoji u svakom mogućem svijetu i da stoga ne postoji mogući svijet u kojem nema barem jedan entitet koji posjeduje kauzalne moći. ${ }^{22}$ Kauzalno prazni svjetovi metafizički su nemogući. Dalje, ako su kozmologijski argumenti uspješni, slijedi da je svemir nužno kauzalno ovisan o nekontingentnom metafizički prvom uzroku pa je stoga metafizički nemoguć ne samo nastanak svemira u kauzalno praznom svijetu, nego općenito neuzrokovan nastanak svemira, tj. nastanak svemira bez vanjskoga djelatnoga uzroka.

Međutim, čak i ako kozmologijski argumenti nisu uspješni argumenti, tj. ako ne uspijevaju dokazati opstojnost prvoga uzroka — primjerice zato što nijedna od onoga što smo nazvali prvim središnjim tvrdnjama kozmologijskih argumenata nije istinita — načelo objašnjenja i načelo utemeljenosti dovoljni su za odbaciti mogućnost spontanoga nastanka svemira ex nihilo. Lako je vidjeti zašto: nastanak

20 Svemir, shvaćen na taj način, uključivao bi i ne-fizičke kontingentne entitete ako takvi postoje, što možda odstupa od uobičajene uporabe izraza "svemir" (usp. bilj. 7), ali u argumentu ništa važno ne ovisi o tom pojednostavljivanju. S druge strane, što je puno bliže standardnoj uporabi toga izraza, uključivao bi sve fizičke entitete u danom mogućem svijetu (pa bi se time odnosio i na fizički svijet koji se sastoji samo od kvantnoga vakuuma, virtualnih čestica i sl.), što prima facie odstupa od načina na koji se izraz svemir rabi kada se kaže da je svemir sâm nastao fluktuacijama u kvantnom vakuumu. No, ponovo, ništa važno u argumentu ne ovisi o tom.

21 Preciznije opisati što bi moglo značiti ono "u" i “iz" ne čini se kao jednostavan zadatak, ali tim gore za onoga tko bi htio tvrditi da svemir može nastati ni iz čega.

22 Da je prvi uzrok metafizički nužan, tj. da postoji u svakom mogućem svijetu, u leibnizovskim argumentima izravno se dokazuje i za njih je rečeno posve nekontroverzno. U tomističkim argumentima nužnost prvoga uzroka slijedi iz toga što bi prvi uzrok, kao kauzalno neovisan, tj. nedrugotan ili neuzrokovan, morao biti actus purus i ipsum esse subsistens (usp. bilj. 12). U kalam argumentima stvar nije toliko očita. Na prvi pogled, kalam dokazuje samo da djelatni uzrok svemira nije nastao, da nema konačnu prošlost, no to je spojivo sa stajalištem da je prvi uzrok samo temporalno vječan, ali ne i nužan. Doduše, kako se u kalamu tvrdnja da svemir ima temporalni početak tipično brani argumentirajući da je temporalna vječnost (preciznije, aktualno beskonačna prošlost) metafizički nemoguća, slijedilo bi da je prvi uzrok, barem bez stvorenoga svemira, atemporalan. Svejedno, ne čini se da atemporalnost sama po sebi izravno implicira metafizičku nužnost. Međutim, jedan od načina na koji se u kalamu argumentira za konačnu prošlost svemira jest argumentirajući da je instancijacija aktualne beskonačnosti općenito metafizički nemoguća, što bi ujedno povlačilo nemogućnost neutemeljenih beskonačnih kauzalnih lanaca. Izravna je posljedica da je metafizički prvi uzrok svemira kauzalno neovisan, iz čega bi metafizička nužnost prvoga uzroka mogla slijediti na sličan način kao i u slučaju tomističkih argumenata, no to bi možda zahtijevalo od branitelja kalam argumenta usvajanje tomističke terminologije i pozadinske metafizike. Craig u svojoj obrani argumenta ne navodi nužnu opstojnost među svojstvima za koja kaže da analizom slijede iz pojma prvoga uzroka (usp. Craig, 2007, 152-154; 2009, 191-194). 
kontingentnih entiteta u kauzalno praznom svijetu nužno bi bila sirova činjenica. U slučaju ontologijski praznoga svijeta stvar je očita. Naime, kako u ontologijski praznom svijetu ne postoji nijedan entitet, ni jedan entitet ne bi eksplanacijski prethodio nastanku svemira i stoga — uzevši u obzir da načelo utemeljenosti eliminira mogućnost relevantnih samoobjašnjavajućih činjenica i samouzrokujućih entiteta - nastanak svemira ničim ne bi mogao biti objašnjen, kauzalno ili kako drukčije. Nastanak svemira bila bi neobjašnjiva kontingentna činjenica. Stvar se puno ne mijenja ni ako dopustimo da u kauzalno praznom svijetu postoje apstraktni entiteti. Naime, čini se jasnim da objašnjenje nastanka kontingentnoga entiteta mora biti kauzalno objašnjenje, a u kauzalno praznom svijetu, postojali u njem apstraktni entiteti ili ne, po definiciji ne postoje entiteti koji mogu stajati u kauzalnim relacijama. Stoga u kauzalno praznom svijetu nijedan entitet ne bi kauzalno prethodio nastanku svemira i stoga nastanak svemira ne bi imao kauzalno objašnjenje. Opet, nastanak svemira bila bi neobjašnjiva kontingentna činjenica. No, vidjeli smo, iz načela objašnjenja slijedi da sirove činjenice nisu moguće.

Dakle, želite li dopustiti nastanak svemira ni iz čega, morali biste odbaciti bilo načelo objašnjenja bilo načelo utemeljenosti. Ako je načelo objašnjenja neistinito, sirove su činjenice moguće i time je, čini se, moguć i spontani nastanak svemira ni iz čega. Samo primijetimo da bi u tom slučaju nastanak svemira ni iz čega i dalje bio sirova činjenica. Međutim, to znači da nastanak svemira ne bi imao objašnjenje — pa time ni znanstveno objašnjenje. Znanost ne bi mogla objasniti kako je svemir nastao. Razlog je bjelodan: što god imalo objašnjenje, po definiciji ne bi bilo sirova činjenica. Malo konkretnije, jedini je način na koji znanosti poput fizike mogu objasniti nastanak nekog entiteta $x$ taj da pokažu kako zakoni prirode, primijenjeni na neku kolekciju prethodno postojećih entiteta, proizvode ili dovode do toga da $x$ postoji, svejedno je li tu riječ o cvijetu maka, crnoj rupi ili svemiru sámom. Međutim, ako je ono što želimo objasniti sam nastanak svemira ni iz čega, tada nemamo na raspolaganju ni fizikalne zakone ni relevantne entitete na koje bismo fizikalne zakone primijenili. Ako je nastanak svemira ni iz čega metafizički moguć, moguć je samo kao neobjašnjiv, bezrazložan događaj. No ako su neobjašnjivi događaji mogući, nema razloga vjerovati da su objektivno malo vjerojatni. ${ }^{23}$ Tko god bio optužen zbog posjedovanja ukradene Van Goghove slike, kazati da je nastanak slike na njegovu zidu tek sirova činjenica činilo bi se tada sasvim razumnom obranom.

Druga je mogućnost odbaciti načelo utemeljenosti, tj. dopustiti da su cirkularni i neutemeljeni beskonačni nizovi objašnjenja eksplanacijski potpuni. Time se otvara mogućnost da nastanak svemira ni iz čega nije neobjašnjiva sirova činjenica, nego da je objašnjiva nekim oblikom kauzalne petlje ili beskonačnoga regresa. Naravno, značilo bi to ujedno da prihvaćate somouzrokujuću kokoš kao

Objektivna vjerojatnost ovisi o zakonima prirode i stoga, ako nekomu događaju možemo pripisati objektivnu vjerojatnost, taj bi događaj imao objašnjenje u terminima zakonā prirode i samim tim činjenica da se događaj u pitanju dogodio ne bi bila sirova činjenica. Nema smisla govoriti o objektivnoj vjerojatnosti sirovih činjenica pa stoga ne možemo ni tvrditi da su neobjašnjivi događaji malo vjerojatni (usp. Pruss, 2006, 273-274; 2009, 28). 
metafizičku mogućnost, a objašnjenje nevjerne zaručnice kao legitimno objašnjenje. Također, vrlo tajnovitom tada postaje činjenica da se padajući glasoviri tako rijetko spontano materijaliziraju. ${ }^{24}$

Obje se opcije čine, kako u kontekstu rasprave o kalam kozmologijskom argumentu piše William Lane Craig $(2009,186)$, »doslovno gore od magije«.

\section{Zaključak}

Ako je prvi stadij bilo kojega standardnoga kozmologijskoga argumenta za Božju opstojnost uspješan, postoji metafizički prvi uzrok, entitet koji, između ostaloga, postoji u svakom mogućem svijetu i referiranjem na koji nužno završava svaki potpuni lanac (kauzalnih) objašnjenja. ${ }^{25}$ No postoji li metafizički prvi uzrok, metafizički je nemoguć spontani nastanak svemira ni iz čega, kao i neuzrokovan nastanak svemira općenito. Obratno, ako nastanak svemira ni iz čega jest metafizički moguć, argumenti za opstojnost prvoga uzroka ne drže vodu. Taj smo odnos između kozmologijskih argumenata i pojma nastanka svemira ni iz čega pokušali u radu detaljnije opisati.

Najprije smo načelnim prigovorom kao trivijalno neistinitu odbacili raširenu tvrdnju da nam suvremena znanost daje (ili barem načelno može ponuditi) objašnjenje nastanka svemira ni iz čega. Analizirali smo zatim tri standardne skupine kozmologijskih argumenata, tvrdeći da svaka od njih počiva na metafizičkim načelima koja smo nazvali načelom objašnjenja i načelom utemeljenosti. Teorijska je funkcija načela objašnjenja odbacivanje kao metafizički nemogućih za argument relevantnih sirovih činjenica. Teorijska funkcija načela utemeljenja isključenje je neutemeljenih eksplanacijskih struktura kao eksplanacijski nepotpunih. Zatim smo pojmu nastanka svemira ni iz čega pokušali dati preciznije značenje, eksplicirajući ga kao nastanak nekoga agregata kontingentnih entiteta u kauzalno praznom svijetu. Pokazali smo potom da konjunkcija načela objašnjenja i načela utemeljenosti, neovisno o kojoj je inačici argumenta riječ, isključuje mogućnost spontana nastanka svemira ex nihilo. Slijedi iz toga da je onaj tko bi htio braniti metafizičku mogućnost nastanka svemira ni iz čega obvezan odbaciti bilo načelo objašnjenja bilo načelo utemeljenosti. Konačno, sugerirali smo da je teorijska cijena bilo koje od tih opcija racionalno neprihvatljiva.

24 Za detaljniju analizu metafizičkih implikacija odbacivanja načela objašnjenja i načela utemeljenosti usp. Lojkić, 2019.

25 Rečenica, strogo gledano, iznosi prejaku tvrdnju. Iako, uzmu li se načelo objašnjenja i načelo utemeljenosti kao metafizički nužne istine, iz prvoga stadija argumenta doista slijedi da u svakom mogućem svijetu postoji neki prvi uzrok, pokazati da je riječ o istom entitetu kroz sve moguće svjetove barem u nekim inačicama kozmologijskih argumenata zahtijeva dodatan posao. No o istovjetnosti prvoga uzroka u svim mogućim svjetovima ne ovisi tvrdnja da uspješnost prvoga stadija argumenta povlači metafizičku nemogućnost nastanka svemira ex nihilo. 


\section{Literatura}

Albert, David (2012). On the Origin of Everything: 'A Universe from Nothing,' by Lawrence M. Krauss. The New York Times Book Review, March 23. URL: https:// www.nytimes.com/2012/03/25/books/review/a-universe-from-nothing-by-lawrencem-krauss.html (19.12.2019.)

Craig, William Lane (2007). Reasonable Faith: Christian Truth and Apologetics. Wheaton: Crossway Books.

Craig, William Lane (2017). God and Abstract Objects: The Coherence of Theism: Aseity. Cham: Springer.

Craig, William Lane; Sinclair, James D. (2009). The Kalam Cosmological Argument. U: William Lane Craig i J. P. Moreland (ur.), The Blackwell Companion to Natural Theology (str. 101-201). Chichester: Wiley-Blackwell.

Feser, Edward (2009). Aquinas: A Beginner's Guide. London: Oneworld.

Feser, Edward (2014). Scholastic Metaphysics: Contemporary Introduction. Heusenstamm: Editiones scholacticae.

Koons, Robert C. (1997). A new look at the cosmological argument. American Philosophical Quarterly, 34(2), 193-211.

Krauss, Lawrence M. (2012). A Universe from Nothing: Why There Is Something Rather Than Nothing. New York: Free Press.

Lojkić, Goran (2019). Metafizički krajobraz ateizma. Obnova: časopis za kulturu, društvo i politiku, 12, 16-59.

O'Connor, Timothy (2012). Theism and Ultimate Explanation: The Necessary Shape of Contingency. Chichester: Wiley-Blackwell.

Pećnjak, Davor (2014). God, Nothing, and Purposeful Universe. U: Evandro Agazzi (ur.), Science, Metaphysics, Religion (str. 154-162). Milano: Franco Angeli.

Pruss, Alexander R. (2006). The Principle of Sufficient Reason: A Reassessment. Cambridge: Cambridge University Press.

Pruss, Alexander R. (2009). The Leibnizian Cosmological Argument. U: William Lane Craig i J. P. Moreland (ur.), The Blackwell Companion to Natural Theology (str. 24100). Chichester: Wiley-Blackwell.

Puljak, Ivica (2018). Kako je svemir mogao nastati iz ničega? Index, 30. listopada. URL: https://www.index.hr/vijesti/clanak/kako-je-svemir-mogao-nastati-iz-nicega/2034910.aspx (27.01.2020.)

Rasmussen, Joshua (2010). From states of affairs to a necessary being. Philosophical Studies, 148(2), 183-200.

Rowe, William L. (2007). Philosophy of Religion: An Introduction. Wadsworth: Cengage Learning.

Toma Akvinski (2005). Izabrano djelo. Izabrao i preveo Tomo Vereš. Drugo znatno prošireno i dotjerano izdanje priredio Anto Gavrić. Zagreb: Nakladni zavod Globus. 


\section{A Universe from Nothing and Cosmological Arguments}

\section{Goran Lojkić*}

\section{Summary}

The aim of the paper is to analyse some conceptual and logical relations between the notion of the spontaneous arising ex nihilo of the Universe and the so-called cosmological arguments for the existence of the First Cause. In the first section, it is argued that no scientific theory could in principle describe the Universe's coming into being from nothing. In the second, three standard classes of cosmological arguments are analysed, and it is claimed that the first phase of every cosmological argument is based on three central premises, including what is termed in the paper 'the principle of explanation' and 'the principle of foundation'. The role of the principle of explanation is to exclude, as metaphysically impossible, relevant kinds of brute facts, and the role of the principle of foundation is to deny the explanatory completeness of certain non-well-founded explanatory chains. In the final section of the paper the notion of coming into being from nothing is given a more precise meaning. It is then argued that the conjunction of the two metaphysical principles in any variant of the cosmological argument excludes the metaphysical possibility that the Universe spontaneously came into being from nothing and that defending the metaphysical possibility of the Universe's arising from nothing therefore commits one to reject either the explanatory principle or the foundation principle. Finally, it is suggested that either option comes at a high metaphysical price.

Key words: cosmological argument; brute facts; explanatory principle; foundation principle; first cause

* Goran Lojkić, Ph.D., Institute of Philosophy in Zagreb. Address: Ulica grada Vukovara 54, 10000 Zagreb, Croatia. E-mail: goran@ifzg.hr 